\title{
Quantitation of angiogenesis factor in bovine retina and tumour extracts by means of radioimmunoassay
}

\author{
S. SHAHABUDDIN AND S. KUMAR
}

From the Christie Hospital, Manchester M20 9BX

SUMMARY Using an antiserum raised against tumour angiogenesis factor (TAF) we have developed a radioimmunoassay for retina and tumour angiogenesis factor(s). This antiserum was previously shown to bind to both human and animal tumour extracts and to inhibit the angiogenesis induced by TAF in vivo. TAF from rat Walker tumour was used for iodination by the chloramine-T method. An excess of ${ }^{125}$ I-labelled TAF was incubated with TAF antibody in the absence (maximum binding) and presence (inhibition of maximum binding) of unlabelled tissue extract. A double antibody technique was used to separate free and bound TAF. Unlabelled human Wilms tumour TAF was used as a standard. The extent of inhibition of ${ }^{125}$ I-TAF-anti-TAF binding provided a measure of TAF in tissue extracts examined. Extracts of normal bovine retina, cornea, lung, aorta, lymph nodes, iris, vitreous humour, and human tumours and normal human pituitary and liver were assayed. Only bovine retina and human tumours were found to contain angiogenesis factor. These findings, together with our earlier results, suggest that angiogenesis factor from both bovine retina and human tumours induce angiogenesis in vivo and possess common antigenic determinants. The presence of angiogenesis factor in healthy retina and its relationship to neovascularisation in clinical conditions is discussed.

Over a decade ago Folkman and his associates demonstrated angiogenesis activity in semipurified extracts of solid tumours. ${ }^{1}$ A number of other investigators have also found such an activity in nontumour sources, particularly retina. ${ }^{2 \rightarrow}$ For instance, Federman et al. reported the growth of limbal vessels in response to retinal tissue implants in rabbit cornea. ${ }^{5}$ More recently extracts of retinal tissues of many species have been shown to contain angiogenesis factor. ${ }^{3 \rightarrow}$ We have also purified an angiogenesis factor from healthy feline ${ }^{3}$ and bovine retinas (unpublished data) which appears to be similar to those isolated previously by us from tumours and synovial fluid of patients with joint disease. ${ }^{2}$ However, the interrelationship and differences between various angiogenesis factors remain unknown. In an earlier report we described the development of 2 immunoassays, radioimmunoassay (RIA) and radioimmunometric assay (RIMA), to quantitate angiogenesis factor in tumour extracts. ${ }^{10}$ In this communication we have used RIA to quantitate angiogenesis factor in bovine retina and tumour extracts.

Correspondence to Dr S. Kumar.

\section{Materials and methods}

RIA buffer. $0 \cdot 1 \mathrm{M}$ phosphate buffer $(\mathrm{pH} 7 \cdot 6)$ containing $0.15 \mathrm{M} \mathrm{NaCl}, 0.05 \%$ sodium azide and $0.5 \%$ bovine serum albumin (Sigma Fraction V Powder).

Tumour angiogenesis factor (TAF). TAF was extracted from rat Walker and human Wilms tumours according to the method described by Phillips and Kumar $^{11}$ and stored lyophilised at $4^{\circ} \mathrm{C}$. The angiogenic substance, although only partially pure, will be referred to as tumour angiogenesis factor (TAF). The TAF was tested by a chorioallantoic membrane (CAM) assay. " Fig. 1 shows a control CAM and 2 other CAMs treated with bovine retina angiogenesis factor and tumour angiogenesis factor. Both tumours and retina angiogenesis factors induced similar stimulation as shown by the spoke-wheel convergence of blood vessels towards the site of TAF application.

Bovine tissue extracts. For each extraction 20 bovine retinas (approximately $10 \mathrm{~g}$ ) were collected from the local abattoir and transported to the laboratory in crushed ice. The extraction procedure involved homogenisation of the tissue in RIA buffer 


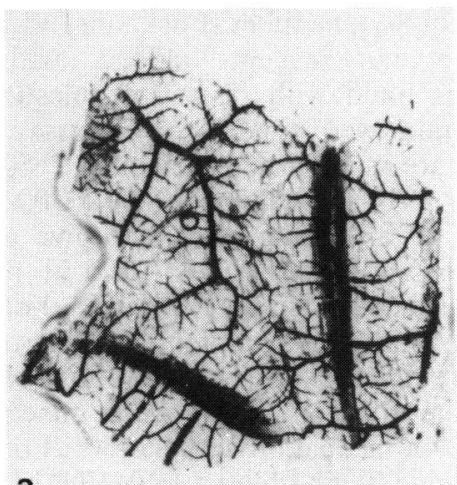

a

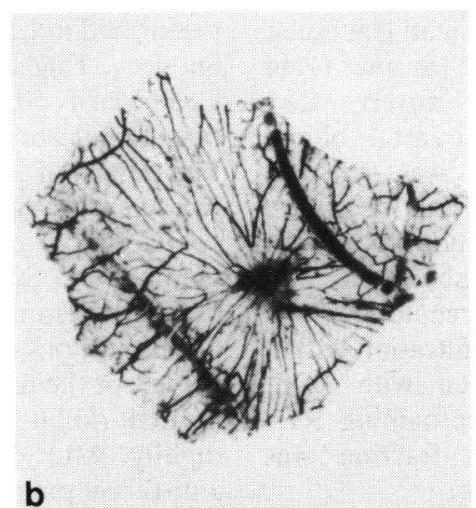

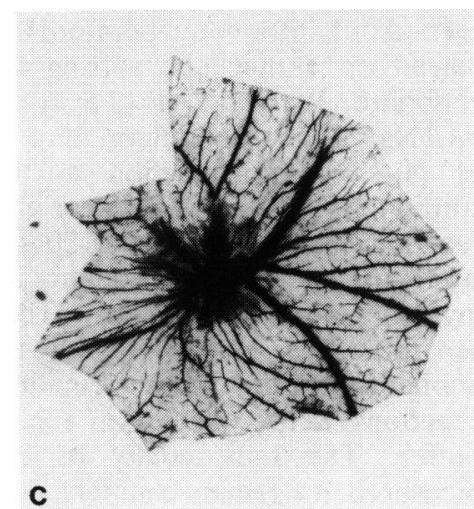

Fig. 1 Chick chorioallantoic membrane: (a) control, (b) showing neovascular response to retinal angiogenesis factor, and (c) tumour angiogenesis factor. In both (b) and (c) newly formed blood vessels converge towards the site of angiogenesis factor application.

$(1 \mathrm{~g} / 5 \mathrm{ml})$ for 3 minutes with a Silverson sealed unit homogeniser. The homogenate was further ultrasonicated for 1 minute ( 2 bursts each lasting 20 seconds). Sonication was followed by centrifugation at $2000 \mathrm{~g}$ for 15 minutes at $4^{\circ} \mathrm{C}$. The supernatant was used for the assay. Normal bovine cornea, lymph node, aorta, and iris were extracted similarly to retinas. The vitreous humour of 3 bovine eyes was pooled and tested by the same assay.

Human tumour and nontumour extracts. Human tumour tissues were surgical biopsy specimens. Normal human pituitary and liver were autopsy material obtained within a few hours of death. All tissues were stored frozen $\left(-20^{\circ} \mathrm{C}\right)$ until required.
Extracts of both tumour and nontumour tissue were prepared by the same method as that used for bovine tissue. Protein was estimated by the method of Lowry et al. ${ }^{12}$

$T A F$ antiserum. An antiserum was raised in a rabbit against rat Walker TAF as described earlier. ${ }^{11}$ It was found to bind to a variety of human and animal tumours (detected by gel diffusion and immunofluorescence) and to inhibit the angiogenesis induced by $\mathrm{TAF}$ in vivo.

Iodination of TAF. Rat Walker TAF was labelled with ${ }^{125} \mathrm{I}$ by the method of Hunter and Greenwood. ${ }^{13}$ All the solutions were made in phosphate-buffered saline (PBS) $(0.05 \mathrm{M} \mathrm{pH} \mathrm{7.6)} \mathrm{The} \mathrm{radioiodination} \mathrm{was}$

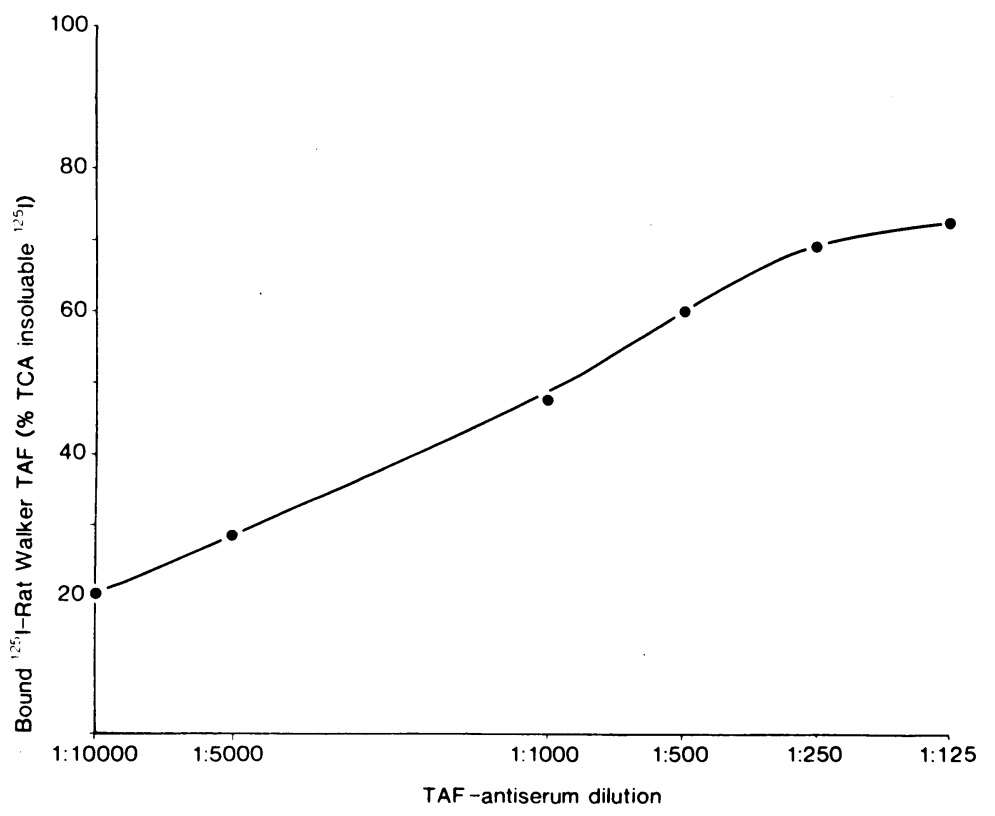

Fig. 2 Binding of ${ }^{125} \mathrm{I}$ rat Walker TAF to TAF antiserum. $50 \mu \mathrm{l}$ of labelled TAF $(50000 \mathrm{cpm})$ was incubated with different dilutions of $T A F$ antiserum in a total volume of $400 \mu l$. The bound ${ }^{125}$ I-TAF was precipitated with a second antibody (see 'Materials and methods'). 
carried out at room temperature in a small glass tube placed on a magnetic stirring table in the fume cupboard. Walker TAF $(2.5 \mu \mathrm{g})$ was mixed with 1 $\mathrm{mCl} \mathrm{Na}{ }^{125} \mathrm{I}$ and $0.1 \mathrm{mg}$ chloramine-T in a total volume of $50 \mu \mathrm{l}$. The reaction mixture was agitated continuously by a metal paper clip. The iodination reaction was stopped after 20 seconds by adding successively $100 \mu$ l of sodium metabisulphite (34 $\mathrm{mg} / \mathrm{ml})$ and $\mathrm{KI}(10 \mathrm{mg} / \mathrm{ml})$. The free iodine was separated from labelled TAF by gel filtration with a Sephadex G-50 column equilibrated with PBS. Fractions were collected in tubes containing RIA buffer. The radioactivity of each fraction was measured in a gamma counter.

TCA precipitation for the estimation of ${ }^{125}$ I-labelled protein. In order to estimate the concentration of ${ }^{125} I$ associated protein $50 \mu \mathrm{l}$ of the fraction of each peak was mixed with $450 \mu \mathrm{l}$ of RIA buffer and $500 \mu \mathrm{l}$ of $10 \%$ TCA solution. After rapid mixing, the tubes were incubated for $30 \mathrm{~min}$ and centrifuged at $2000 \mathrm{~g}$ for $30 \mathrm{~min}$ at $4^{\circ} \mathrm{C}$. The supernatants were discarded and the radioactivity in the pellet was measured.

Competitive binding of labelled TAF and unlabelled tissue extracts to the TAF antiserum (radioimmunoassay). The binding of ${ }^{125}$ I Walker TAF to serial dilutions of the TAF antiserum and the competition between the labelled TAF and unlabelled tissue extract for the antibody binding sites was studied by the standard radioimmunoassay (RIA) technique. ${ }^{14}$ A double-antibody technique was used to separate bound and free antigen. ${ }^{15}$ Unless specified, dilutions were made in the RIA buffer. All assays were performed in LP3 polystyrene tubes (Luckham Ltd., Sussex, England) and reagents added with Eppendorff pipettes fitted with disposable plastic tips. Duplicate samples were used for every assay. The details of RIA are as published previously. ${ }^{10} 50$ $\mu \mathrm{l}$ of a ${ }^{125}$ I Walker TAF (containing 30000-60000 $\mathrm{cpm}), 100 \mu \mathrm{l}$ of TAF antiserum diluted to give a binding with $50 \%$ of the iodinated TAF, $100 \mu$ l of buffer (to estimate maximum binding), or $100 \mu$ l of serial dilutions of Wilms TAF (to obtain a standard curve), or the tissue extracts to be tested and $150 \mu$ l of normal rabbit serum (diluted 1:300) were mixed rapidly. After $16-20 \mathrm{~h}$ incubation at $4^{\circ} \mathrm{C}, 150 \mu \mathrm{l}$ of anti-rabbit precipitating serum (diluted 1:10) (RD17. Wellcome Reagents, Beckenham, Kent, England) was added. To estimate the concentration of proteinassociated ${ }^{125} \mathrm{I}, 150 \mu \mathrm{l}$ of $40 \%$ TCA solution was added to the controls instead of the anti-rabbit precipitating serum. The tubes were incubated overnight at $4^{\circ} \mathrm{C}$, followed by centrifugation at $2000 \mathrm{~g}$ for $30 \mathrm{~min}$ at $4^{\circ} \mathrm{C}$. The supernatant was discarded and the radioactivity in the residues was measured in a gamma counter.

\section{Results}

Gel filtration of different batches of ${ }^{125}$ I-labelled Walker TAF produced 3 or 4 peaks. The percentage of ${ }^{125} \mathrm{I}$ protein (TCA precipitable) varied between $94 \%$ in the first to about $4 \%$ in the fourth batch. Peak 1 was found to bind to TAF antiserum. In a few instances peak 2 also bound to antiserum. In such
Fig. 3 Inhibition of ${ }^{125}$ I rat Walker TAF-anti-TAF binding by human Wilms TAF. ${ }^{125}$ I rat Walker $(45000 \mathrm{cpm})$ was incubated with $T A F$ antiserum diluted 1:1600 in a total volume of $400 \mu l$. In the absence of unlabelled TAF, $25 \%$ of the TCA-insoluble ${ }^{125}$ I was bound to the antiserum. Binding in the presence of different concentrations of Wilms TAF is expressed as a percentage of that maximum binding.

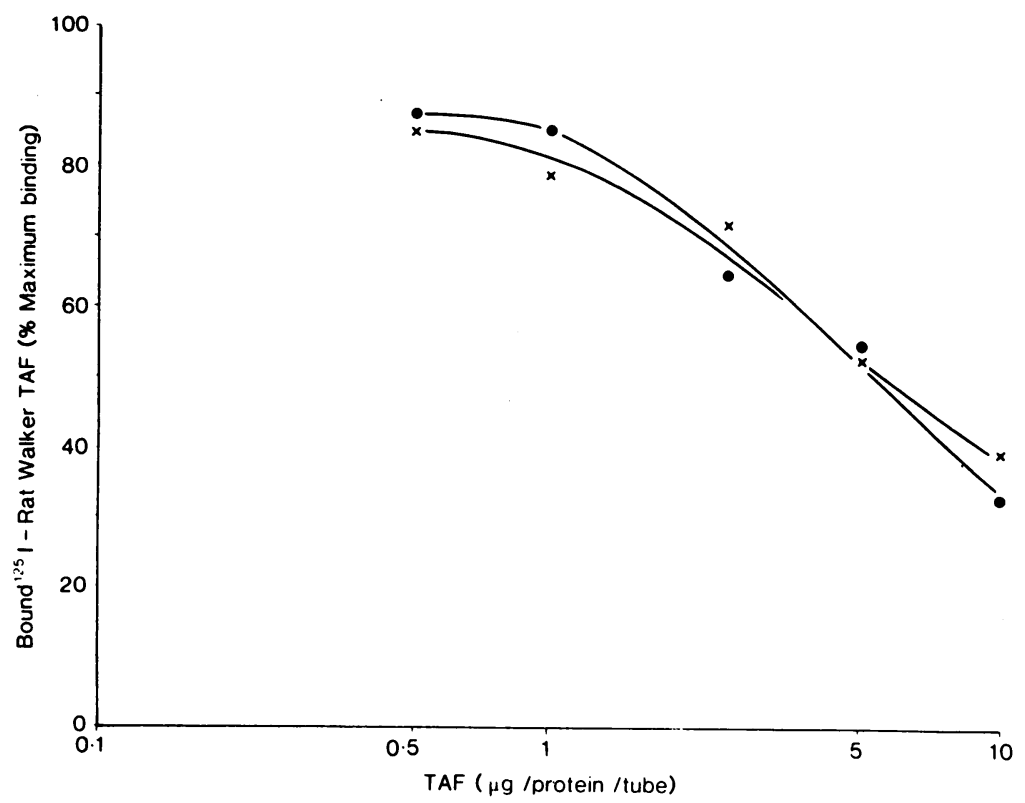




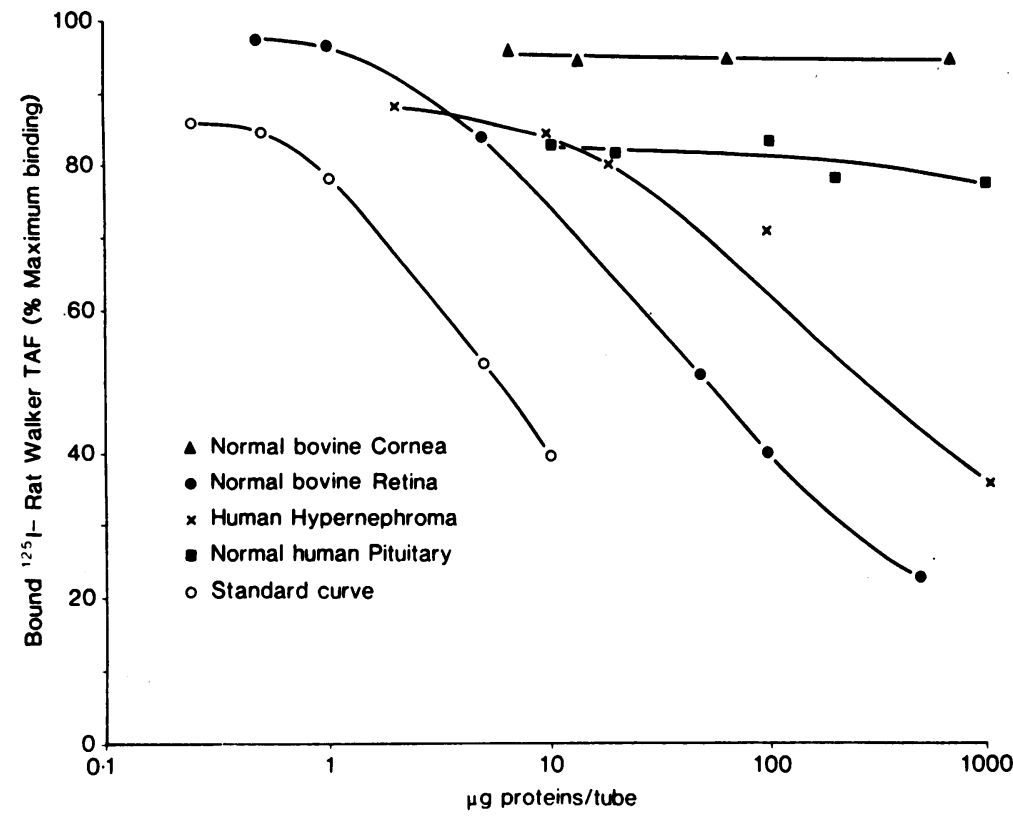

Fig. 4 Inhibition of ${ }^{125}$ I rat Walker TAF-anti-TAF binding by various tissue extracts.

Experimental details were the same as those in Fig. 3.

cases the first 2 peaks were pooled. The specific activity ranged between 10 and $14 \mu \mathrm{Ci} / \mu \mathrm{g}$ TAF protein. Antiserum titration was carried out by incubating a constant amount of ${ }^{125}$ I Walker TAF with different dilutions of the antiserum (1:125 to 1:10000).

Fig. 2 illustrates the antiserum titration curve. At least duplicate samples were used for every assay; the standard deviations were less than $10 \%$ of the mean. The inhibition of ${ }^{125}$ I Walker TAF and anti-TAF binding by unlabelled Wilms TAF provided a standard curve for the assay.

Fig. 3 shows 2 standard curves obtained by two different batches of Wilms TAF. The displacement induced by the unlabelled tissue extracts provided the inhibition curves which were compared with the standard curve. There was parallelism between the standard curve produced by Wilms TAF and the inhibition curves produced by both bovine retina and

Table 1 Tissue samples were extracted and assayed by RIA for angiogenesis factor, and the results were expressed in terms of wet weight and protein weight as described in the text

\begin{tabular}{|c|c|c|c|}
\hline \multirow[t]{2}{*}{ Tissue extract } & \multirow[t]{2}{*}{ Numbers examined } & \multicolumn{2}{|l|}{$T A F$} \\
\hline & & $\mu g / g$ wet $w t$. & $\mu g / \mu g$ protein \\
\hline \multicolumn{4}{|l|}{ Bovine } \\
\hline Retina & 3 & $2640 ; 1986 ; 378$ & $0.11 ; 0.06 ; 0.0045$ \\
\hline Cornea & 3 & 0 & 0 \\
\hline Lung & 3 & 0 & $\mathbf{0}$ \\
\hline Lymph node & 3 & 0 & $\mathbf{0}$ \\
\hline Aorta & 3 & 0 & $\mathbf{0}$ \\
\hline Iris & 2 & 0 & 0 \\
\hline $\begin{array}{l}\text { Vitreous humour } \\
\text { Human } \\
\text { (a) Tumours }\end{array}$ & 2 & 0 & 0 \\
\hline Wilms & 3 & $1134 ; 1260 ; 718$ & $0 \cdot 018 ; 0 \cdot 02 ; 0 \cdot 104$ \\
\hline Oesteochondroma & 1 & 2025 & 0.016 \\
\hline Hypernephroma & 1 & 1344 & 0.028 \\
\hline Lymphoma & 1 & 48 & 0.001 \\
\hline Glioma & 2 & $869 ; 665$ & $0.01 ; 0.0075$ \\
\hline $\begin{array}{l}\text { Fibrosarcoma } \\
\text { (b) Normal tissues }\end{array}$ & 1 & 370 & 0.017 \\
\hline Pituitary & 1 & 54 & 0.001 \\
\hline Liver & 1 & 65 & 0.001 \\
\hline
\end{tabular}




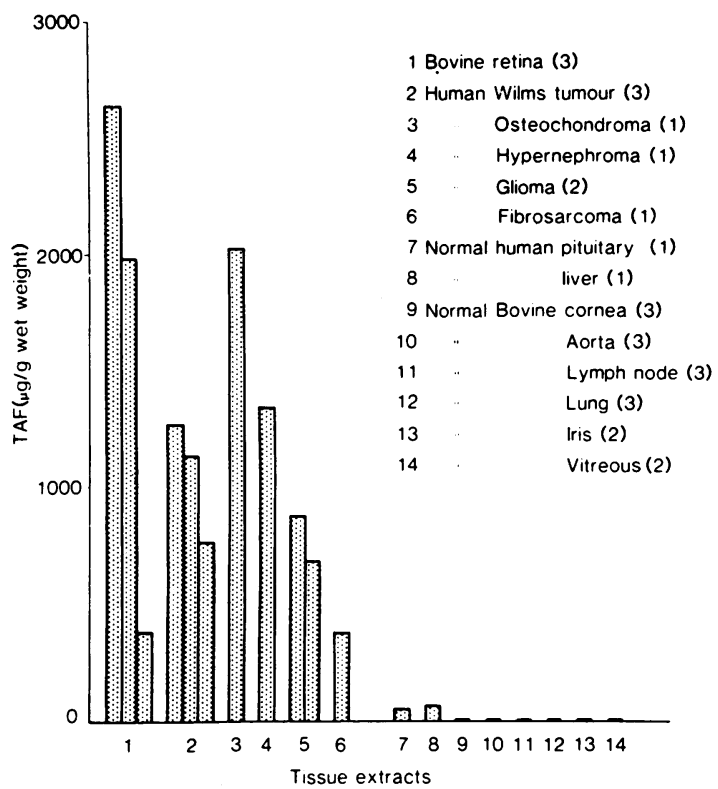

Fig. 5 Bovine and human tissue extracts were assayed for angiogenesis factor by RIA. The levels of angiogenesis factor in different types of tumour and nontumour tissue extracts are compared. The number of different tissue extracts examined is indicated in parentheses.

human tumour extracts (Fig. 4). This indicated an immunological identity between Wilms TAF and the extracts of bovine retina and human tumours.

The quantity of angiogenesis factor in a tissue extract producing an inhibition of the maximum binding was expressed as the quantity of Wilms TAF

Table 2 Amounts of various extracts ( $\mu$ g protein) needed to obtain $25 \%$ inhibition of ${ }^{125}$ I-TAF-anti-TAF binding

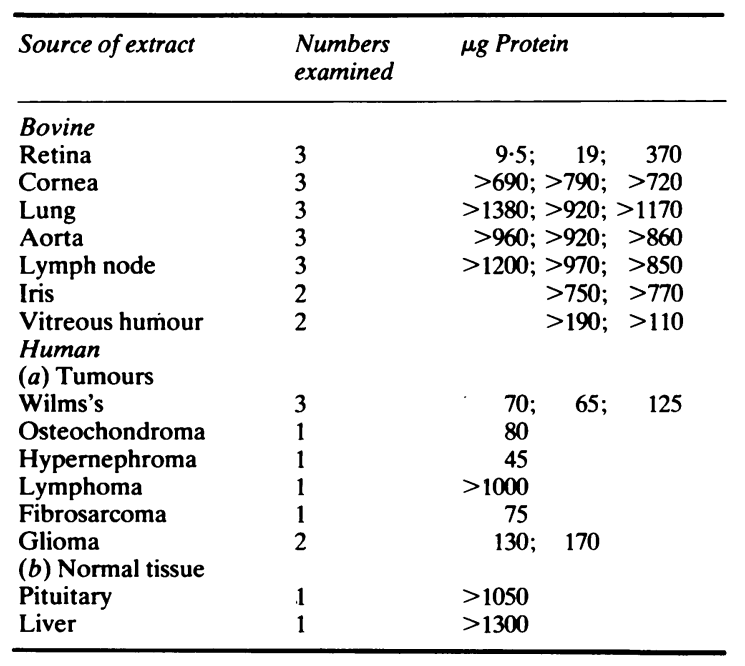

producing similar inhibition. The values for angiogenesis factor were expressed as both $\mu \mathrm{g} \mathrm{TAF} / \mathrm{g}$ wet weight and $\mu \mathrm{g} \mathrm{TAF} / \mu \mathrm{g}$ protein of the tissue (Fig. 5 and Table 1). The level of angiogenesis factor in retinal extracts varied from 378 to $2640 \mu \mathrm{g} \mathrm{TAF} / \mathrm{g}$ wet weight. Extracts of other normal bovine tissues did not inhibit the binding to any significant extent, that is, the angiogenesis factor if present in these tissues could not be detected by the present RIA. Considerable inhibition was produced by all human tumour extracts but not by either normal human pituitary or liver. The values for different tumour types varied from 48 to $2025 \mu \mathrm{g} \mathrm{TAF} / \mathrm{g}$ wet weight.

The detection limits (defined as the amount of protein producing $25 \%$ inhibition of the maximum binding) of the assay are shown in Table 2.9.5-370 $\mu \mathrm{g}$ protein of the retinal extracts and 45-170 $\mu \mathrm{g}$ protein of the human tumour extracts were required to produce $25 \%$ inhibition.

\section{Discussion}

We have developed a radioimmunoassay (RIA) for an angiogenesis factor from bovine retina using an antiserum raised against rat Walker TAF. This antiserum has been previously reported to bind to human and animal tumours (detected by gel diffusion and immunofluorescence) and to inhibit TAF induced angiogenesis in vivo. ${ }^{11}$ Our data show that TAF and the extracts of bovine retina and human tumours possess common antigenic determinant(s), which are either absent or present only in much smaller concentrations in normal human pituitary and liver and bovine aorta, lung, cornea, iris, lymph node, and vitreous humour. The inhibition curves produced by retinal and tumour extracts were parallel to those produced by Wilms TAF. The amounts of angiogenesis factor, estimated as equivalent of Wilms TAF, were equal or slightly more in bovine retinal extracts compared with tumour extracts. These findings confirm and significantly extend our previous work. ${ }^{3}$ Partially and highly purified extracts from tumours and healthy feline ${ }^{3}$ and bovine retinas (unpublished data) were found to give an angiogenic response on the chick chorioallantoic membrane. These extracts also bound to TAF antiserum linked to a sepharose affinity column. Furthermore, D'Amore et al. have also isolated an angiogenesis factor from normal bovine retina. ${ }^{9}$ The structural identity of tumour or retinal angiogenesis factor(s) is not known.

For a solid tumour to grow beyond a size of a few cubic $\mathrm{mm}$ it needs the formation of new blood vessels, and thus the role of angiogenesis factor in tumours is obvious. Why a large amount of angiogenesis factor is present in normal retina and why its presence does not induce angiogenesis requires an explanation 
Henkind has suggested that, for retinal neovascularisation to occur, both an abnormal retinal vascular bed and a vasculogenic factor produced by a hypoxic retina are required. ${ }^{16}$ If vascular perfusion is relatively good the retinal vessels will not proliferate, even though a vasculogenic substance is present.

Another explanation for the absence of neovascularisation of healthy retina may be that vitreous humour has been shown to contain substances that inhibit the growth or new blood vessels by tumour angiogenesis factor. ${ }^{17-19}$ Such inhibitors may be involved in controlling the activity of any retinal angiogenesis factor. It is also possible that healthy retina itself may contain inhibitors in addition to activators (TAF) to maintain an equilibrium. The marked variation in the quantity of angiogenesis factor among 3 retinal extracts (see Table 1) can be explained by the above conditions.

Diabetic retinopathy, retrolental fibroplasia, and sickle cell retinopathy are common examples of clinical conditions where retinal neovascularisation occurs. The likeliest cause of these conditions seems to be venous occlusion or ischaemia resulting in hypoxic retinal tissue. As mentioned earlier, Henkind has suggested that such hypoxic tissue can liberate a vasculogenic stimulator. The proposed vasculogenic stimulator may be the same as angiogenesis factor. ${ }^{162021}$

In summary, using a radioimmunoassay we have demonstrated for the first time a bovine retinaderived substance immunologically identical to tumour angiogenesis factor. The role of angiogenesis factor in diseases where retinal neovascularisation occurs needs investigation.

\section{References}

1 Folkman J, Merler E. Abernathy C. Williams G. Isolation of a tumour factor responsible for angiogenesis. J Exp Med 1971; 133: 275-88.

2 Brown RA, Weiss JB. Tomlinson IW. Phillips PJ, Kumar S. Angiogenesis factor from synovial fluid resembling that from tumours. Lancet 1980; i: 682-5.
3 Kissun RD, Hill CR, Garner A, Phillips PJ, Kumar S, Weiss JB. A low molecular weight angiogenesis factor in cat retina. $\mathrm{Br} J$ Ophthalmol 1982; 66: 165-9.

$4 \mathrm{Chen} \mathrm{CH}$, Chen SC. Angiogenic activity of vitreous and retinal extract. Invest Ophthalmol Visual Sci 1980; 19: 596-602.

5 Federmann JL, Brown GC. Feldberg NT, Felton SM. Experimental ocular angiogenesis. Am J Ophthalmol 1980; 89: 231-7.

6 Kissun RD, Garner A. Vasoproliferative properties of normal and hypoxic retinal tissues. Br J Ophthalmol 1977; 61: 394-8.

7 Glaser BM. D'Amore PA. Michels RG, et al. The demonstration of angiogenic activity from ocular tissues. Preliminary report. Ophthalmology 1980;87: 440-6.

8 Glaser BM. D'Amore PA. Michels RG, Patz A. Fenselau A. Demonstration of vasoproliferative activity from mammalian retina. J Cell Biol 1980; 84: 298-304.

9 D'Amore PA, Glaser BM, Brunson SK, Fenselau AH. Angiogenic activity from bovine retina. Partial purification and characterization. Proc Natl Acad Sci USA 1981; 78: 3068-72.

10 Schor AM, Kumar S. Phillips PJ. Quantitation of extracts containing tumour angiogenesis factor (TAF) by radioimmunometric and radioimmunoassays. Int J Cancer 1980; 25: 773-9.

11 Phillips PJ, Kumar S. Tumour angiogenesis factor (TAF) and its neutralization by a xenogeneic antiserum. Int J Cancer 1979; 23: 82-8.

12 Lowry OH, Rosebrough NJ, Farr AL, Randall RJ. Protein measurement with the folin phenol reagent. J Biol Chem 1951; 193: $265-5$.

13 Hunter WM, Greenwood FC. Preparation of iodine-131 labelled human growth hormone of high specific activity. Nature 1962; 194: 495-6.

14 Yallow RS, Berson SA. Immunoassay of endogenous plasma insulin in man. J Clin Invest 1960; 39: 1157-75.

15 Hunter WM. Ganguli PC. The separation of antibody bound from free antigen. In: Kirkham KE, Hunter WM, eds. Radioimmunoassay. Edinburgh and London: Churchill Livingstone. 1971: 243-57.

16 Henkind P. Ocular neovascularization. Am J Ophthalmol 1978; 85: 287-301.

17 Brem S, Brem H, Folkman J, Finkelstein D, Patz A. Prolonged tumor dormancy by prevention of neovascularization in vitreous. Cancer Res 1976; 36: 2807-12.

18 Brem S, Preis I, Langer R, Brem H, Folkman J, Patz A Inhibition of neovascularization by extract derived from vitreous. Am J Ophthalmol 1977; 84: 323-8.

19 Felton SM, Brown GC, Felberg NT, Federman JL. Vitreous inhibition of tumor neovascularisation. Arch Ophthalmol 1979; 97: 1710-3.

20 Casel GH. A clinical prospective on retinal neovascularization research. Ann Ophthalmology 1982; 14: 713-6.

21 Michaelson IC. The mode of development of the vascular systems of the retina with some observations on its significance for certain retinal disease. Trans Ophthalmol Soc UK 1948; 68: 137-80. 